\title{
Correction to: OnabotulinumtoxinA in Chronic Migraine: A Profile of Its Use
}

\author{
James E. Frampton ${ }^{1}$
}

Published online: 16 January 2021

(c) Springer Nature Switzerland AG 2021

\section{Correction to: CNS Drugs (2020) 34:1287-1298 https://doi.org/10.1007/s40263-020-00776-8}

The article OnabotulinumtoxinA in Chronic Migraine: A Profile of Its Use, written by James E. Frampton, was originally published electronically on SpringerLink on 11 December 2020 without open access. After publication in volume 34, issue 12, page 1287-1298, AbbVie requested that the article be Open Choice to make the article an open access publication. Post-publication open access was funded by AbbVie. Therefore, the copyright of the article has been changed to $\odot$ Springer Nature Switzerland AG 2020 and the article is forthwith distributed under the terms of the Creative Commons Attribution NonCommercial 4.0 International License, which permits any non-commercial use, sharing, adaptation, distribution and reproduction in any medium or format, as long as you give appropriate credit to the original author(s) and the source, provide a link to the Creative Commons licence, and indicate if changes were made. The images or other third party material in this article are included in the article's Creative Commons licence, unless indicated otherwise in a credit line to the material. If material is not included in the article's Creative Commons licence and your intended use is not permitted by statutory regulation or exceeds the permitted use, you will need to obtain permission directly from the copyright holder. To view a copy of this licence, visit http://creativecommons .org/licenses/by-nc/4.0/".

The original article has been corrected.

Open Access This article is licensed under a Creative Commons Attribution-NonCommercial 4.0 International License, which permits any non-commercial use, sharing, adaptation, distribution and reproduction in any medium or format, as long as you give appropriate credit to the original author(s) and the source, provide a link to the Creative Commons licence, and indicate if changes were made. The images or other third party material in this article are included in the article's Creative Commons licence, unless indicated otherwise in a credit line to the material. If material is not included in the article's Creative Commons licence and your intended use is not permitted by statutory regulation or exceeds the permitted use, you will need to obtain permission directly from the copyright holder. To view a copy of this licence, visit http://creativecommons.org/licenses/by-nc/4.0/. 